\title{
NEW TECHNOLOGIES AND THE CURRENT COMMUNICATIONS MODEL IN THE 2018 BRAZILIAN ELECTIONS
}

\section{NOVAS TECNOLOGIAS E OS HODIERNOS MODELOS DE COMUNICAÇÃO NAS ELEIÇÕES BRASILEIRAS DE 2018}

\section{NUEVAS TECNOLOGÍAS Y LOS HODIERNOS MODELOS DE COMUNICACIÓN EN LAS ELECCIONES BRASILEÑAS DE 2018}

\section{Edilene Lôbo²}

\section{José Luiz Bolzan de Morais ${ }^{3}$}

Licença CC BY:

Artigo distribuído sob os termos Creative Commons, permite uso e distribuição irrestrita em qualquer meio desde que o autor credite a fonte original.

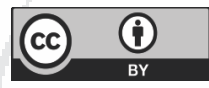

\begin{abstract}
This article considers the impact of new technologies in the 2018 Brazilian elections, and investigates the possibilities of changes due to the prominent use of social networks to directly connect citizens and candidates, without the customary intervention of political parties and traditional media. It also questions the role of fake news in the electoral process, and the means to fight it, without undermining free thought, as an essential human right for the practice of citizenship in the new digital age.
\end{abstract}

Keywords: Democracy; New Technologies, Political Pluralism, Fake News.

1 This text presents the first approach to the post-doctoral research problem of the co-author, under the orientation of Professor Jose Luis Bolzan de Morais of the PPGD (Postgraduate Program in Law) of the Law School of Vitória/ES with the title Democracia, Novas Tecnologias e Instituições e Garantias Eleitorais (Democracy, New Technologies and Electoral Institutions and Guarantees). The paper was developed during the co-author's time as a Visiting Scholar at the University of Seville, Spain, in January 2019, under the supervision of the Professor Alfonso JuliosCampuzano, PhD of the Philosophy of Law Department.

2 Master of Law, Federal University of Minas Gerais. Doctorate in Law (PhD), Pontifical Catholic University of Minas Gerais. Teacher of the Post-Graduation Program of the University of Itaúna. Email: edilenelobo@yahoo.com.br.

3 Master of Law, Pontifical Catholic University of Rio de Janeiro, Doctorate in Law (PhD), Federal University of Santa Catarina and Université de Montpellier I - France. Research Production Fellowship at CNPq (National Council for Scientific and Technological Development) - Level 1D. Teacher of the Post-Graduation Program in Law of the University of Itaúna, Law School of Vitória and Dom Helder Câmara Law School. State Attorney of Rio Grande do Sul/BR at the superior courts, Brasília/DF. E-mail: bolzan@hotmail.com. 


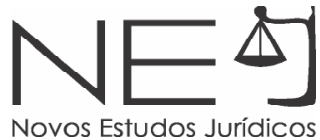

Resumo: O presente artigo considera o impacto das novas tecnologias nas eleições do Brasil de 2018 e investiga as possibilidades de mudanças trazidas pelo uso marcado de redes sociais para conectar de forma direta cidadãos e candidatos, sem a usual intervenção de partidos políticos e mídia tradicional. O estudo também questiona o papel das "fake news" no processo eleitoral e os meios para combatê-las, sem deteriorar a Liberdade de pensamento como um direito humano fundamental para a prática da cidadania em uma nova era digital.

Palavras-chave: Democracia; Novas Tecnologias, Pluralismo Político, Fake News.

Resumen: El presente artículo considera el impacto de las nuevas tecnologías en las elecciones de Brasil de 2018 e investiga las posibilidades de cambios traídos por el uso marcado de redes sociales para conectar de forma direta ciudadanos y candidatos, sin la usual intervención de partidos políticos y media tradicional. El estudio también cuestiona el papel de las "fake news" en el proceso electoral y los medios para combatirlas, sin deteriorar la Libertad de pensamiento como un derecho humano fundamental para la práctica de la ciudadanía en una nueva era digital.

Palabras-clave: Democracia; Nuevas Tecnologías, Pluralismo Político, Fake News.

INTRODUCTION

Since Paleolithic times, man has sought to go beyond his own limits through technology. The image of primitive man making artefacts out of flint rock, the discovery of fire, the written word, the use of the printing press, the telegraph, the radio, electricity, and the dissemination of television, through to today's communication era and the eradication of geographical or spatial limitations by means of the Internet, are symptomatic of the relentless technological evolution and its application to all areas of life.

The First Industrial Revolution, a major milestone of Western society, brought the use of steam engines to increase production. This was a period in which the technological process received a huge stimulus, and was vastly accelerated in the decades that followed, up until the Second World War. This was followed by the massive use of robotics in industry, and then, at the end of the second millennium, the introduction of new communications technologies at the heart of the cybernetic evolution - already regarded as a fifth-generation fundamental right. ${ }^{4}$

4 WOLKMER, Antônio Carlos. Introdução aos fundamentos de uma teoria geral dos "novos" direitos Retrieved from: http://www.egov.ufsc.br/portal/sites/default/files/593-2009-1-pb.pdf, on Jan. 16, 2019. 
We live is a society of sensors ${ }^{5}$, in which investments are made in clairvoyant computers that use mathematical analyses of past data supplied by humans connected to the network.

There are sensors everywhere, inserted in fully automated smart homes, built into cellphones, watches, bracelets, clothes, automobiles and home appliances, generating sounds, images, numbers, feelings and emotions. This results in people and environments that are monitored and give off data, which is accumulated, processed and mined, transforming information into money or power. ${ }^{6}$ The "network" is the new ideology of boundless capitalism.

This escalation affects all walk of life, from the most intimate personal leisure or sensory spaces to our professional lives, including politics, where it transforms democracy, revolutionizing the vote as a mechanism of external control of public representation. The expansion of popular participation through social networks via the Internet gives a new face to democracy, stemming from the instantaneity of the flow of information, the suppression of physical barriers, and the sense of direct cooperation with political representatives.

The network communication that overthrew governments, incited social movements and elected important leaders throughout the World, brought politics to the heart of families, opposing generations, eradicating physical distances and limits to the debate, be it age, subject, or even the veracity of the information (for example, fake news, which should be treated as a dysfunction that contaminates freedom of communication and the right to be correctly informed).

Destroying the myth of neutrality, this communication also enables an invisible and alien manipulation, as seen in the recent scandal in the United States of America that resulted in accusations that the election of Donald Trump was down to the interference of Russian agents acting against his opposing candidate,

$5 \quad$ NETO, Elias Jacob de Menezes; BOLZAN DE MORAIS, José Luís. ANÁLISES COMPUTACIONAIS PREDITIVAS COMO UM NOVO BIOPODER: MODIFICAC̄ÕES DO TEMPO NA SOCIEDADE DOS SENSORES. Revista Novos Estudos Jurídicos - Digital, Vol. 24 - n. 3 - Sep-Dec 2018, p. 1.129-1.154 Retrieved from: https://siaiap32.univali. br/seer/index.php/nej/article/view/13769/7808, on Jan. 15, 2019.

6 NETO, Elias Jacob de Menezes; BOLZAN DE MORAIS, José Luís. ANÁLISES COMPUTACIONAIS PREDITIVAS COMO UM NOVO BIOPODER: MODIFICAÇÕES DO TEMPO NA SOCIEDADE DOS SENSORES. Revista Novos Estudos Jurídicos - Digital, Vol. 24 - n. 3 - Sep-Dec 2018, p. 1.139. Retrieved from: https://siaiap32.univali.br/ seer/index.php/nej/article/view/13769/7808, on Jan. 15, 2019. 
Hilary Clinton, whose political ideology was not as favorable to them (ending in a criminal lawsuit before the Grand Jury of the District of Columbia ${ }^{7}$ ).

Another dramatic example that has led to an ongoing crisis in Europe, is the debacle over Brexit, the UK referendum on whether to stay in or leave the European Union. In this case it was the company Cambridge Analytica, hired by the group that wanted to leave the European bloc, that came under the spotlight. As in the Donald Trump case, the company used personal data from millions of Facebook users to create a software program that was able to influence voters' choices, by targeting particular groups in its publicity investments and manipulating their personal data to actually steer the outcome of the referendum. Francisco Balaguer Callejón cites both cases as clear examples of democratic regression that affects a State's volition construction, made internal by the work of global agents in search of their own interests ${ }^{8}$, already unveiling the networks' lack of neutrality. Despite this, the positive potential of the networked society is immense, stimulating popular participation in the management of public affairs, bringing new communication channels to the traditional rigid model that currently prevails, and in crisis, representative democracy, the possibility of giving greater visibility of powers through the access to information related to the practices of the State, and its managers ${ }^{9}$.

However, there is a need to invest in educational public policies that will enable citizens to fight digital illiteracy. Educating is still an inexpensive and long-lasting remedy against manipulation through hate and prejudice. It also enables the development of abilities for appropriate use of technology, where for leisure, at work, in schools, within the family and, fundamentally, in politics. Furthermore, because not everything is rosy in the digital realms exploited by the great capitalistic platforms, the development of effective mechanisms of control, regulation and accountability is crucial to avoid rights violations.

\footnotetext{
7 CRIMINAL NO. 18 U.S.C. $\S \S 2,371,1349,1028$ A. EUA vs INTERNET RESEARCH AGENCY LLC et al. Retrieved from: https://www.justice.gov/file/1035477/download, on Dec. 16, 2018.

8 CALLEJÓN, Francisco Balaguer. LAS DOS GRANDES CRISIS DEL CONSTITUCIONALISMO FRENTE A LA GLOBALIZACIÓN EN EL SIGLO XXI. Roma: Rivista Nomos Le Atualittà nel Diritto. N. 2, Dec. 2018, p. 2. Retrieved from: http://www.nomos-leattualitaneldiritto.it/wp-content/uploads/2018/09/Callehon.-conv-11.05.pdf, on Jan. 23, 2019.

9 In Brazil, for example, there was the adoption of the LAI: Information Access Law, no. 12.527/2011.
} 
Therefore, the theorem is how to utilize new technologies to interconnect people, reduce distances between local and global areas, and update and strengthen human rights and democracy itself.

With this picture in mind, this paper aims to promote the debate in order to offer contributions to the exercise of citizenship in social networks, in Brazil, having political rights as an immediate horizon. A literature review and jurisprudence research were the techniques adopted to reach the conclusions presented at the end, all under the benchmark of citizenship and pluralism as foundations of the State (Art. 1, subsections II, III and V, of the Brazilian Constitution), which has the duty to promote and stimulate scientific and technological qualification (Art. 218 of the Brazilian Constitution).

The paper is divided into three parts. It begins with a broad overview of the subject in the Brazilian elections and the use of WhatsApp as a publicity vehicle with free and simple access, but that enables the creation of fiefdoms, hindering the flow of dissenting information and external control due to its endto-end encryption. This section also presents the debate over the app access interruption as a sanction to collective rights violation in direct accountability to the technology owner.

The paper then addresses the communications model that the new technologies used in the Brazilian elections, going beyond the old paradigm of radio and TV as the major media vehicles of political rights and the possibility of exclusion of political parties. Lastly, we investigate the manipulation of the network as an abuse of the media vehicle - an illicit act that should be investigated by the control bodies in order to hold accountable all those involved, whether users or beneficiary candidates (including the platforms themselves, due to the malicious use of technology). 


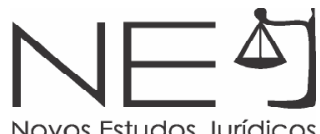

\section{THE 2018 BRAZILIAN ELECTIONS IN THE “NETWORK”}

The impact of new technologies, particularly the prominent role of chat groups in the last Brazilian elections, has amplified the debate over the necessary protections of political guarantees, even more so when it comes to individual rights to communication, especially the right to free thought formation and pluralism, which are keys to the legitimacy of the democratic system.

The work focuses, in particular, on the intense viral spread of fake news and hate speech without any limitations, secretly encoded by end-to-end encryption, with evidence of manipulation by economic groups seeking to influence the result of the election ${ }^{10}$. The use of personal data to access the network illicitly ${ }^{11}$ and the boosting of content without legal authorization were present, in stark opposition to the law, and going against the inviolability of privacy, a legal tenet of the Brazilian Civil Rights Framework for the Internet ${ }^{12}$, created to allow some governance over the network. Just as in the United Kingdom with the Brexit referendum, and in the USA with the use of Facebook in the Donald Trump elections, the Brazilian campaign strategy regarding WhatsApp was to create an "ecosystem"13 out of "interests that are not restricted [only] to politics"14.

Esther Solano Gallego explains that WhatsApp groups are formed like fiefdoms, "based on proximity, affinity and trust relations where strangers and those that dare to disturb the harmony with dissenting opinions will be blocked ${ }^{15}$, prohibiting the flow of divergent positions.

10 MELLO, Patrícia Campos. Empresários bancam campanha contra o PT pelo WhatsApp. São Paulo: Folha de São Paulo, story from October 18 2018. Retrieved from: https://www1.folha.uol.com.br/amp/poder/2018/10/ empresarios-bancam-campanha-contra-o-pt-pelo-whatsapp.shtml, on Oct. 19, 2018.

11 MELLO, Patrícia Campos; RODRIGUES, Arthur. El uso fraudulento de documentos de personas físicas hizo posible el disparo masivo de mensajes de WhatsApp durante las elecciones brasileñas. São Paulo, story from December 3, 2018. Retrieved from: https://www1.folha.uol.com.br/internacional/es/brasil/2018/12/el-uso-fraudulentode-documentos-de-personas-fisicas-hizo-posible-el-disparo-masivo-de-mensajes-de-whatsapp-durante-laselecciones-brasilenas.shtml, on Dec. 4, 2018.

12 BRASIL. Presidência da República. Law no. 12.695, April 23, 2014. Estabelece princípios, garantias, direitos e deveres para o uso da internet no Brasil. Brasília. Diário Oficial da União of April 24, 2014. Retrieved from:http:// www.planalto.gov.br/ccivil_03/_ato2011-2014/2014/lei//12965.htm on Jan. 06, 2019.

13 ROQUE, Tatiana e BRUNO, Fernanda. A natureza da desinformação. Newspaper Folha de São Paulo, Section Ilustríssima, p. 6, Nov. 18, 2018.

14 ROQUE, Tatiana e BRUNO, Fernanda. A natureza da desinformação. Newspaper Folha de São Paulo, Section llustríssima, p. 6, Nov. 18, 2018.

15 GALLEGO, Esther Solano. La whatsapización de la politica y la nueva verdad. Contexto Review, n. 196, Nov. 21, 2018. Digital. Retrieved from: https://ctxt.es/es/20181121/Firmas/23006/elecciones-brasil-whatsappizacionpolitica-fake-news-esther-solano.htm, on Nov. 26, 2018. 
This is the negative nodal point of this communications practice because "without dissenting opinions there is no democracy"16. It also prepares "the terrain to the spread of fake news in an undemocratizing information process" ${ }^{\prime 17}$.

Turning communications into a fiefdom, supported by superstition and prejudice, created to cloud and accentuate fear, also brings under the spotlight a lack of belief in the traditional scientific process of mediation to interpret the facts of politics.

In the past, "it was socially agreed and established that politicians, the press, teachers, andintellectuals were the mediators to understand the World"18 opening up possibilities to the path of knowledge and information. The point is that nobody knows anymore who decides what's true, even if it is temporary and factual ${ }^{19}$, in the disintermediation process that flows into anti-intellectualism and ignorance as virtues. It is the fighting of science with post-truth and the defense of the apolitical as a safeguard in the public arena. Oreste Massani ${ }^{20}$ says that the misery of the new populist political class reverberates in all of the public life, poisoning it.

The struggle against falsehood and hate as an electoral campaign engine can only be won through digital literacy, with human rights education and good quality information produced by multiple media channels, guided by basic ethics of information publishing: the presentation of facts without distortion and with

16 GALLEGO, Esther Solano. La whatsapización de la politica y la nueva verdad. Contexto Review, n. 196, Nov. 21, 2018. Digital. Retrieved from: https://ctxt.es/es/20181121/Firmas/23006/elecciones-brasil-whatsappizacionpolitica-fake-news-esther-solano.htm, on Nov. 26, 2018.

17 GALLEGO, Esther Solano. La whatsapización de la politica y la nueva verdad. Contexto Review, n. 196, Nov. 21, 2018. Digital. Retrieved from: https://ctxt.es/es/20181121/Firmas/23006/elecciones-brasil-whatsappizacionpolitica-fake-news-esther-solano.htm, on Nov. 26, 2018.

18 GALLEGO, Esther Solano. La whatsapización de la politica y la nueva verdad. Contexto Review, n. 196, Nov. 21, 2018. Digital. Retrieved from: https://ctxt.es/es/20181121/Firmas/23006/elecciones-brasil-whatsappizacionpolitica-fake-news-esther-solano.htm, on Nov. 26, 2018.

19 POPPER, Karl. A lógica da pesquisa científica. Translator Leonidas Hegenberg e Octanny Silveira da Mota. São Paulo: Cultrix, 1974.

20 MASSARI, Oreste. DAL PARTITO DI MASSA ALLA PARTITOCRAZIA SENZA PARTIT. Roma: Rivita Nomos Le Atualittà Nel Diritto. Antecipazioni convegni no. 3, del 2018, p. 30. Retrieved from: http://www.nomosleattualitaneldiritto.it/wp-content/uploads/2019/01/Massari-contributo-su-Zangara-3.2018.pdf, on Jan. 23, 2019. Original text: "Il risultato è che i leader e la classe politica del populismo fondamentalista esibiscono un mix di ignoranza (anche nella grammatica e nella sintassi), incompetenza, approssimazione, semplicismo e arroganza impressionanti, dileggiando chi li contraddice o ha idee diverse o è investito di autorità (sia scientifica che politica). È la miseria della nuova classe politica populistica. Ma è una miseria che si riverbera su tutta la vita pubblica avvelenandola." 
reliable and responsible checking of sources. There should be a constant stimulus to free press and to multiple means of communication, as this will avoid the focus on reflection inhibiting immediatism and promote a process of intellectual maturing in plural societies. All this should occur, while not neglecting the urgent needs to investigate the formative structure of the network, which is extremely nebulous and is controlled by diverse economic interests, and to build new habits that will break the spell that enthralls so many citizens connected to the network. This is one of the basic elements in the use of the network, which claims to fulfil the promise made in the Brazilian Constitution: to foster and encourage technological training ${ }^{21}$ in order to achieve political emancipation in the digital age. Pedro Garcia Aguado and Francisco Castanho Mena suggest educating children to keep them safe in social networks, with good examples, autonomy, control and responsibility, major contributions to creating basic public policy for the benefit of young people as well as adults ${ }^{22}$.

Besides education, another essential element is control over the use and flow of other source of information and leisure, paying heed to the crucial warning from Francisco Balaguer Callejón regarding the multiple technical means used by the network to manipulate public opinion. ${ }^{23}$

21 BRASIL. Presidência da República. Constituição da República Federativa do Brasil. Published in Diário Oficial da União of Oct. 05, 1988. Retrieved from: http://www.planalto.gov.br/ccivil_03/Constituicao/Constituicao.htm, Dec. 4, 2018).

22 AGUADO, Pedro García y MENA, Francisco Castaño. A salvo en la red. Cómo proteger y educar a tus hijos en internet y las redes sociales. Barcelona: Penguin Random House Grupo Editorial, 2017, p. 200. Original text: "El buen uso de las redes sociales, el smartphone, los videojuegos, las aplicaciones... depende de los valores que enseñemos em casa (y se enseña sobre todo con ele ejemplo); depende también de las normas y los límites que regulen los tiempos e el modo de uso, siempre desde la coherencia y el cariño; depende del apoyo que las nuevas tecnologías receban en el colégio, y depende de que nuestros hijos disfruten explorando, descubriendo y aprediendo día trás día. La educación em el siglo XXI no puede passar por alto ninguno de estos detalles, porque las nuevas tecnologias son nuestro presente y nos enseñam por qué caminhos avanzaremos en el futuro. Si la educación es autonomia, cariño, responsabilidade, gestión y crecimiento, los es también com respeto a internet y a las redes sociales, parte indispensável de nuestra vida. Avanzar todos a uma, bien equipados de experiencias positivas, trucos e maneras de educar, es nás necesario que nunca."

23 CALLEJÓN, Francisco. LAS DOS GRANDES CRISIS DEL CONSTITUCIONALISMO FRENTE A LA GLOBALIZACIÓN EN EL SIGLO XXI. Roma: Rivita Nomos Le Atualittà Nel Diritto. N. 2, del 2018, p. 10. Retrieved from: http://www.nomos-leattualitaneldiritto.it/wp-content/uploads/2018/09/Callehon.-conv-11.05.pdf, on Jan. 23, 2019. Original text: "La interacción entre redes sociales y democracia comienza a ser problemática. La reflexión sobre esa tensión creciente se ha centrado hasta ahora en la incidencia negativa de las redes sociales en el espacio público en cuanto que la creación de perfiles está generando filtros que producen burbujas (...) en las que quedan 'aislados' los usuarios, provocando diversas disfunciones. Entre ellas, la fragmentación del espacio público, la radicalización creciente de los diversos sectores de opinión que se mueven dentro de esas 'burbujas', la proliferación de las fake news, que se ve favorecida por la lógica de la polarización (...)." 
Control, after education, would protect deliberative democracy, ensuring that for the adequate shaping of public opinion, a multiplicity of individuals and points of view present in the social setting are represented and allow a small perspective of what is to come.

\subsection{WHATSAPP AND JUDICIAL CONTROL}

The number one social networking app in Brazil, WhatsApp ensures anonymity to the many members of its exponential chain of contacts. Its ease of use makes it a powerful tool, within reach of everybody, requiring only a cellphone and Internet access. From there to global access, without spatial boundaries, it is just a matter of time. Little time, by the way, it can reach a community of more than one billion people ${ }^{24}$, integrating it at the same time.

Group communication, made secret by the encryption of WhatsApp, ensures that only the recipient of the message has the key to unscramble the information from the sender, effectively creating the ideal environment for the toxic sharing of hate speech and fake News that irradiate through the network without limitation, weakening this communications channel in its innovative generational role in politics.

The siege on dialogue leads to the impoverishment of the communications process, producing illiteracy and intolerance. Strictly speaking, it hits the heart of democracy because hostility towards the different, ${ }^{25}$ and the manipulation of the masses through information manipulation ${ }^{26}$ is an age-old strategy used to dominate the masses. It is equally an illicit capable of imposing liability for the social damage caused, because speech has the power to violate collective rights, particularly political ones, and in this case it cannot be hidden under the guise of individual free speech.

24 This number was reached in July 2017, as stated in the company's blog. Retrieved from: https://blog.whatsapp. com/?l=pt_br, on Dec. 09, 2018.

25 Ferrajoli very well speaks of them subject in the third chapter of his work, highlighting that the crisis of democracy passes through the "denigrazione dei dissenzienti e dei diversi". (FERRAJOLI, Luigi. Poteri selvaggi. Roma: Laterza, 2011, p. 41-57).

26 FERRAJOLI, Luigi. Poteri selvaggi. Roma: Laterza, 2011, p. 55. 


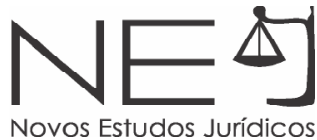

Citizenship is the practice of participating in the public life, with emphasis on the communication process to debate, vote and take part in public affairs; "these rights are only fully put into action when the information available to the public is not manipulated in accordance with some interest, public or private"27

In this context, the State cannot renounce the control and restriction of this technology to protect human rights. It must activate the Brazilian Civil Rights Framework for the Internet, inaugurated with Law no. 12.965 of April 23, 2014. This law contains important rules on network governance and protection for users, setting out sanctions that include warnings, fines, temporary suspension and even the prohibition of activities.

In 2016, Brazil experimented with the controversial suspension of WhatsApp, reaching the Federal Supreme Court through abstract constitutionality action no. 5.527 and the claim of non-compliance with fundamental precept no. 403. On those occasions, the Federal Supreme Court lifted the block that had been placed due to the company's refusal to provide data on users allegedly involved in criminal activities. The precautionary measure was imposed due to a supposed protection of freedom of communication, leaving a thorough exam to the ruling on the merit of the actions ${ }^{28}$.

Afterwards, exploring the subject in a public hearing ${ }^{29}$, the Federal Supreme Court chose elements linked to the right to information and to be informed, pondering on the limits to the judge acts, outside of the institutions of electoral guarantees, because the act was performed during a period of time previous to the elections, and the app was not experimented with in the electoral process.

27 DIAS, P.Y. Regulação da internetcomo administração da privacidade. Revista de Direito, Estadoe Telecomunicações. Brasília, v. 9, n. 1, May 2017, p. 172.

28 BRASIL. Supreme Federal Tribunal. Arguição de Descumprimento de Preceito Fundamental no. 403. Relator Ministro Edson Facchin. Decision from July 19, 2016. Retrieved from: http://stf.jus.br/portal/diarioJustica/ verDiarioProcesso. asp?numDj=152\&dataPublicacaoDj=01/08/2016\&incidente $=4975501 \&$ codCapitulo=6\&numMa teria $=117 \&$ codMateria=10, on Jan. 19, 2019.

29 BRASIL. Supreme Federal Tribunal. Simultaneous Public Hearing Called to Discuss Aspects of Articles 10 and 12, II and IV, of Law 12,965/2014 - Marco Civil da Internet (ADI 5.527, Rel. Min. Rosa Weber) - e a Suspensão do Aplicativo WhatsApp por Decisões Judiciais no Brasil (ADPF 403, Rel. Min. Edson Fachin). Brasília, Ending in Jun. 5th, 2017. Retrieved from: http://www.stf.jus.br/arquivo/cms/audienciasPublicas/anexo/ ADI5527ADPF403AudinciaPblicaMarcoCivildalnterneteBloqueioJudicialdoWhatsApp.pdf, on Jan. 18, 2019. 
Although incomplete, significant contributions from pundits, companies and entities involved are presented, making it clear that up to 2014, the app was not encrypted, showing the possibility of reverse engineering, nowadays, to remove the privacy from conversations between users, when the illicit use is verified, breaking the major point of the platform to prevent control.

It was also made evident that the block does not hinder usage of the network by other apps or providers, there being no obstruction to the right to be informed by other channels - logically, this does not exempt sanctions of being adopted as a last resource and supported on logical and coherent justification, under the substantial adversarial procedure, so that it does not join the ranks of arbitrariness involving the network.

Elsewhere, the duty of the system administrators to maintain a connections register is evident, as determined by the Brazilian Civil Rights Framework for the Internet, in order to check potential criminal links. Under the terms of the same defining law, if, after a judicial order, the provider does not make the questioned content available, then it may be held liable for individual and/or collective damages.

From the public hearing, it is possible to start the debate regarding the governance of the "technological tools present in each electoral period"30, outlining public policy dedicated to "good practices in electoral campaigns on the Internet"31.

The debate should also include the promotion of self-regulation, at the initiative from the platforms themselves, and the participation of civil society. In the case of WhatsApp, for example, this means:

a) a ban on sending messages to infinite groups of recipients, a precaution already adopted in other countries;

30 As determined by Art. 57-J of Law no. 9.504/97. In: BRASIL. Presidência da República. Law 9.504, of setembro 30, 1997. Estabelece normas para as eleições. Brasília, Diário Oficial da União de $1^{\circ}$ de outubro de 1997. Retrieved from: http://www.planalto.gov.br/ccivil_03/LEIS/L9504.htm, on Dec. 4th, 2018.

31 As determined by Art. 57-J of Law no. 9.504/97. In: BRASIL. Presidência da República. Law 9.504, of September 30, 1997. Estabelece normas para as eleições. Brasília, Diário Oficial da União of October 1, 1997. Retrieved from: http://www.planalto.gov.br/ccivil_03/LEIS/L9504.htm, on Dec. 4th, 2018. 
b) a continual effort to identify fake accounts or those manipulated by bots;

c) the creation of efficient communication channels for user complaints, and the suspension of the manipulated accounts, with the publication of periodical reports;

d) the adoption of educational programs on democratic good practices, publishing messages that promote respect for different opinions, sexual freedom, and pluralism;

e) reserving slots for free political publicity, allowing access by the poor;

d) keep a list of communication vehicles or webpages of fact-checking entities, allowing source checking and notification of fake news;

g) the adoption of an ombudsman comprised of various sectors of society;

Actually, in reference to the broad control, accompanied by the internal effort, the signing of national and international treaties is essential to internet governance in search of transparency and cooperation of the platforms, seeking to protect goods and political rights as benchmarks.

\section{NEW MODELS IN ELECTORAL COMMUNICATION}

without a doubt, the use of technological instruments in the electoral area, in Brazil, is nothing new. Announced in the eighties ${ }^{32}$, and driven by the first electronic voting in the $1996^{33}$ elections, these instruments nowadays use biometrics that allow the identification of each voter through the capture of personal data from an electronic fingerprint-activated terminal, and reinforced by the online registration of the voter ${ }^{34}$. Also, the explosion of applications that give access to services provided by the electoral judicial branch, such as voter

32 By the Law no. 6.996, of June 7, 1982, and Law no. 7.444, of December 20, 1985, that regulated the use and electronic processing of data in the electoral services.

33 Determined by Law no. 9.100, of September 29, 1995, that the vote reception will use an electronic ballot box, nowadays incorporating biometrics.

34 The candidacy registration request has become fully electronic, including the transmission of biographical info over the internet. This system is currently regulated by the Resolution no. 23.548/2017 of the Superior Electoral Tribunal, making possible real time checking and from anywhere on the planet through the Internet. 
registration ${ }^{35}$, electoral illicit reporting ${ }^{36}$, internet fundraising, and the real time submission of campaign accountancy reports ${ }^{37}$, bring another perception to the communication model in vogue.

Today is different from the time when proximity was face-to-face between candidates and citizens; the vote was made on a paper ballot and the major communication vehicles, the so called hot media, were radio and TV.

Curiously, as recalled by Oreste MAssari, television broke into the political campaigns "starting with the famous debate between Nixon and Kennedy on September 26, 1960" 38 , and was for many years, the star player in electoral processes. In Brazil, it reached its peak in the 2014 campaign with the debate between Dilma and Aécio during the second round, reaching millions of viewers at prime time. However, there was a sharp decline in TV audiences in the 2018 election, due to the communications migration to social networks, as commented ahead in this paper.

Aware of the use of technology in the electoral area, it doesn't require too much imagination to admit the possibility of completely virtual elections in the near future, through the use of the block chain ${ }^{39}$

35 The e-título is an electronic version of the voter registration card that can be used to vote. The tool is available in virtual stores, as Play Store or Web Store, and needs just the voter personal data to generate a QR Code to crosscheck the apps information and the electoral judicial branch database.

36 Named sparrow, this application allows the reporting of illicit acts, including the transmission of photos and other data about the infringement using the network directly to the electoral judicial branch.

37 The accounts disclosing provide remote access to all candidates' data and their accountancy, such as amount and source of financing, allocation of spending, direct and indirect donors, that is, allows the checking of the formal financing of candidacies.

38 MASSARI, Oreste. DAL PARTITO DI MASSA ALLA PARTITOCRAZIA SENZA PARTIT. Roma: Rivita Nomos Le Atualittà Nel Diritto. Antecipazioni convegni no. 3, del 2018, p. 10. Retrieved from: http://www.nomosleattualitaneldiritto.it/wp-content/uploads/2019/01/Massari-contributo-su-Zangara-3.2018.pdf, on Jan. 23, 2019.

39 Blockchain, a chain of blocks, is explained this way: "Imagine a huge notebook, in which the content is public and free to access and in which all the transactions made in the world are registered. The most interesting part is that the notebook is collective written, through consensus, in a way that every financial user can ceaselessly check the noted information. In a simplified way, the blockchain would be this notebook. It is an enormous decentralized and public data bank that, in the case of Bitcoin, monitors who is the owner of a certain amount of bitcoins. (...)." (TAVARES, João Felipe Chagas e TEIXEIRA, Luiz Felipe Drummond. BLOCKCHAIN: DOS CONCEITOS ÀS POSSÍVEIS APLICAÇÕES. In: POLIDO, Fabricio Bertini Pasquot; ANJOS, Lucas dos; BRANDÃO, Luíza Couto Chaves (Orgs.). TECNOLOGIAS E CONECTIVIDADE. DIREITO E POLÍTICAS NA GOVERNANÇA DAS REDES. Belo Horizonte: Instituto de Referência em Internet e Sociedade, 2018, p. 118-121. 


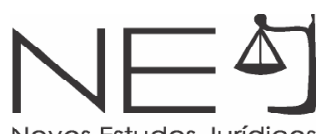

For example, since 2005, Estonia has had a ballot placed by cellphone ${ }^{40}$, and in Sierra Leone, for the first time in March 2018, experimenting with booths in one region ${ }^{41}$, recently the Saratov Oblast region of southern Russia elected a member of the Youth Parliament by means of this technology, in December 2018, in a decentralized network distributed over voting booths, in a poll that lasted around seven hours and had a turnout of forty thousand voters. ${ }^{42}$ Before Russia, Switzerland and the USA State of West Virginia made state parliamentary elections using the block chain ${ }^{43}$.

Just a short distance from surpassing the already advanced paradigm of the electronic ballot box, questions arise concerning electoral publicity, which we shall answer in the next topic: Is the hot media benchmark obsolete?

\subsection{ELECTORAL PUBLICITY IN THE NETWORK: THE OVERCOMING OF THE RADIO AND TV COMMUNICATION PARADIGM}

Under the technological influx, electoral publicity, previously concentrated in vehicles as radio and TV, was transferred to instant messaging apps such as Facebook, Twitter, Instagram and video hosting, with the creation of channels on YouTube.

This shows an apparent surpassing of the radio and TV paradigm as the primary forms of disseminating information in the electoral dispute. This was seen in the state elections for governor in Rio de Janeiro and Minas Gerais, in which both winning candidates - first -time runners in small and little known coalitions or parties - won by considerable margins of $71.80 \%$ and $59.87 \%$, respectively, leavening behind long-time leaders and of command over this technology ${ }^{44}$. The

40 GOMES, Helton Simões. Voto em casa e pelo celular! Como é a tecnologia em eleições pelo mundo. Uolnotícias.com. Published on October 27, 2018. Retrieve from: https://noticias.uol.com.br/tecnologia/noticias/redacao/2018/10/27/ votar-em-casa-e-com-blockchain-como-e-a-tecnologia-em-eleicoes-pelo-mundo.htm, on Jan. 15, 2019.

41 MÜLLER, Leonardo. Primeira eleição do mundo auditada por blockchain é realizada em Serra Leoa. Techmundo. com. Published on March 16, 2018. Retrieved from: https://www.tecmundo.com.br/software/128285-primeiraeleicao-mundo-auditada-blockchain-realizada-serra-leoa.htm, on Jan. 15, 2019.

42 ROCHA, Luciano. Região na Rússia conduz a primeira eleição em blockchain do país. Criptomoedasfácil.com. Published on December 20, 2018. Retrieved from: https://www.criptomoedasfacil.com/regiao-na-russia-conduz-aprimeira-eleicao-em-blockchain-do-pais/, on Jan. 16, 2019.

43 ROCHA, Luciano. Região na Rússia conduz a primeira eleição em blockchain do país. Criptomoedasfácil.com. Published on December 20, 2018. Retrieved from: https://www.criptomoedasfacil.com/regiao-na-russia-conduz-aprimeira-eleicao-em-blockchain-do-pais/, on Jan. 16, 2019.

44 BRASIL. TSE. Elections results. Retrieved from: http://www.tse.jus.br/eleicoes/estatisticas/estatisticas-eleitorais, on Jan. 13, 2019. 
presidential election gives yet more examples, although in that case, the elected candidate was not a newbie, having been member of the federal parliament for around thirty years. The difference was the pioneering use of private networks made by WhatsApp, and the public communications through Twitter, Facebook, Instagram and YouTube, abandoning debates on television, reinforcing the instantaneity of direct contact between candidate and voters, and transforming mass communication surrounding the elections.

The digital revolution has reached the masses in a wholly expansive manner ${ }^{45}$, imposing the modernization of communicative and representative acts, as affirmed by Perez Luño and supported by Habermas. ${ }^{46}$ This has occurred without abandoning the hot media, but its role has significantly diminished. Thus, traditional political institutions, such as political parties, must appropriate the new communication models, overcoming the analog format and looking for some mediation in the digital society ${ }^{47}$, paying heed to the warning of Manuel Castells that self-communications of the masses should be a technological platform for the culture of autonomy. ${ }^{48}$

This autonomy, also announced by Perez Luño ${ }^{49}$, allows "the direct and immediate participation of citizens," 50 heading towards a society with no political parties, as he defended, but not without the risk of the "privatization of what is public by a charismatic leader". ${ }^{51}$ In other words, direct connection can create personalism, fertile ground for populism, as seen in the recent elections in the

45 CASTELLS, Manuel. A sociedade em rede. A era da informação: economia, sociedade e cultura. Vol.1. Translators Roneide Venâncio Majer. 18a edição, revista e ampliada. São Paulo: Paz e Terra, 2017.

46 PEREZ LUÑO, Antônio-Enrique. Teledemocracia, ciberciudadania y derechos humanos. Revista Brasileira de Políticas Públicas. Brasília, v. 4, n. 2, Jul-Dec 2014, p. 4. Retrieved from: https://www.publicacoesacademicas. uniceub.br/RBPP/article/view/2835, on Jan. 15, 2019.

47 GRACCO, Abraão Soares Dias dos Santos; SILVA ÂNGELUS, Alcione. Partidos políticos analógicos e a necessidade de mediação em uma sociedade digital. In: GUERRA, Arthur Magno e Silva; BARACHO JÚNIOR, José Alfredo de Oliveira; BERNARDES, Flávio do Couto (Orgs.). 30 Anos de Democracia. Belo Horizonte: Editora D'Plácido, 2018, p. 123-146.

48 CASTELLS, Manuel. Redes de indignação e esperança: movimentos sociais na era da internet. Rio de Janeiro: Zahar Editores, 2013.

49 LUÑO, Antônio-Enrique Pérez. Teledemocracia, cibercidadania y derechos humanos. Revista Brasileira de Políticas Públicas, Brasília, v. 4, n. 2, 2014, p. 8-46. Retrieved from: https://www.publicacoesacademicas.uniceub. br/RBPP/article/view/2835, on Jan. 15, 2019.

50 LUÑO, Antônio-Enrique Pérez. Teledemocracia, cibercidadania y derechos humanos. Revista Brasileira de Políticas Públicas, Brasília, v. 4, n. 2, 2014, p. 17. Retrieved from: https://www.publicacoesacademicas.uniceub.br/ RBPP/article/view/2835, on Jan. 15, 2019.

51 GRACCO, Abraão Soares Dias dos Santos; SILVA ÂNGELUS, Alcione. Partidos políticos analógicos e a necessidade de mediação em uma sociedade digital. In: GUERRA, Arthur Magno e Silva; BARACHO JÚNIOR, José Alfredo de Oliveira; BERNARDES, Flávio do Couto (Orgs.). 30 Anos de Democracia. Belo Horizonte: Editora D’Plácido, 2018, p. 126. 
USA, Italy, Hungary, Poland and Brazil. ${ }^{52}$ Another problem is the atomization of social relations, reinforcing the prevalence of the strongest (not necessarily the best and most elaborate argument in favor of democracy) in the defense of their own marketing benefit, guided by global agents, as reported by Francisco Balaguer Callejón ${ }^{53}$. In addition, the rejection of traditional processes of popular demonstration in favor of direct connection to political leaderships ushers in a kind of end of the State, in a "process of deconstitutionalization"54 and emptying of its structures, placing the democratic model in danger and reviving the old authoritarian way of power sharing between the ruling elite ${ }^{55}$ to the detriment of the people.

\subsection{THE PLACE OF FREEDOM}

For any deliberative society that wants to be long-lasting, it is essential to save politics as the place of freedom ${ }^{56}$ against manipulation, discrimination and prejudice, structuring it so as to implement citizenship as a vector for the full fruition of political rights inseparable from democratic plurality. With this value identified, it becomes clear that what is called new, is actually old. The means may have changed (i.e. the communication technology), but the longstanding formula of making and accumulating wealth at the expense of manipulation and human rights violations is the same, in the deliberate

52 To achieve an excellent understanding of the world phenomenon, it is recommended the reading of RIVERO, Ángel, ZARZALEJOS, Javier y PALACIO, Jorge (Coordinators). Geografia del populismo Um viaje por el universo del populismo desde sus orígenes hasta Trump. Madrid: Tecnos, 2017.

53 CALLEJÓN, Francisco Balaguer. LAS DOS GRANDES CRISIS DEL CONSTITUCIONALISMO FRENTE A LA GLOBALIZACIÓN EN EL SIGLO XXI. Roma: Rivita Nomos Le Atualittà Nel Diritto. N. 2, del 2018. Retrieved from: http://www.nomos-leattualitaneldiritto.it/wp-content/uploads/2018/09/Callehon.-conv-11.05.pdf, on Jan. 23, 2019.

54 BOLZAN DE MORAIS, José Luis. O fim da geografia institucional do Estado. A "crise" do Estado de Direito. In: BOLZAN DE MORAIS, José Luis (Organizer). Estado \& Constituição: o fim do estado de direito. $1^{\text {a }}$ ed. Florianópolis: Tirant Lo Blanc, 2018, p. 21.

55 According to Alfonso de Julios-Campuzano: "Un análisis superficial de la historia reciente nos puede llevar a la conclusión de que el gran triunfador de nuestro tempo es el sistema democrático como forma de organización política. Pero, desafortunadamente, no parece que esta conclusión sea del todo correcta. Cierto es que la democracia moderna - entendida como sistema de organización política que distribuye el poder entre la cidadania mediante formas representantivas de gobierno - es hoy una realidade triunfante, generalmente extendida más allá del contexto geográfico em que vino a nacer. Pero podemos plantearnos si esse sistema de organización política responde efectivamente a las exigências de articulación de formas esencialmente democráticas de organización social, esto es, si la democracia es, em nuestros dias, um modelo de organización social que obedece a los postulados emancipatorios de liberdad e igualdad reales, o si trata tan sólo uma forma de reparto de cuotas de poder entre las elites dominantes."(JULIOS-CAMPUZANO, Alfonso de. La Crisis de Legitimidad em Las Democracias Contemporaneas. Partidos Politicos, Movimentos Sociales Y Ciudadania Responsable. In: BOLZAN DE MORAIS, José Luis (Organizer). Estado \& Constituição: o fim do estado de direito. $1^{\text {a }}$ ed. Florianópolis: Tirant Lo Blanc, 2018, p. 157).

56 ARENDT, Hannah. A Promessa da Política. São Paulo: Editora Difel, 2008. 
Novos Estudos Jurídicos

alienation of the "game rules"57. Constitutional rules of democracy aimed at mutual tolerance and modelled on pluralism need to be revived, "preventing the routine of political competition to become a free-for-all" 58 stimulated by interests prejudicial to citizens.

In Brazil, the electoral courts are responsible for inspecting and enforcing those constitutional rules of democracy. They are special branches whose function should be to enforce guarantees to the virtual or in real life practice of citizenship. There is therefore an urgent need for Legal-State breaches to be immobilized in regard to network manipulation. Manuel Castells emphasizes that the relation between society and technology is an interest of the State and its power institutions, considering that it is a "decisive factor in the general process, as it reflects and organizes social forces". .99

Technological advancements should be used to reinforce citizenship, without neglecting the need for instruments capable of safeguarding against human rights abuses.

This means that the branches and control of inspection urgently require an understanding of the use and destination of new technologies, without surrendering to global market-fed individualism, a predator of local interests, or the refusal of the offers that intelligence brings to new systems of rights.

The balance between collective and individual interests cannot create uncertainty over the assertion of the first and relativize the later, always starting on the process-guarantee structured in broad defense, adversarial proceeding and in the reasoning of decisions

57 LEVITSKY, Steven; ZIBLATT, Daniel. Como As Democracias Morrem. Rio de Janeiro: Zahar, 2018.

58 LEVITSKY, Steven; ZIBLATT, Daniel. Como As Democracias Morrem. Rio de Janeiro: Zahar, 2018, p. 103.

59 CASTELLS, Manuel. A sociedade em rede. A era da informação: economia, sociedade e cultura. Vol.1. Translator Roneide Venâncio Majer. 18ª edição, revista e ampliada. São Paulo: Paz e Terra, 2017, p. 31. 


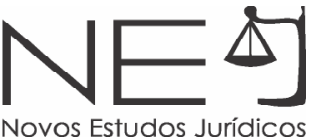

\subsection{FREEDOM AND ANONYMITY IN THE POLITICAL ARENA}

Political publicity is one of the collective rights that is essential to the democratic process because it is the means by which citizens can inform and be informed about propositions, ideas, projects and programs from parties and candidates, allowing them to form opinions that will lead to choices. This right is structured in freedom of speech; however, it does not accept anonymity, as determined in subsection IV of Art. 5 of the Brazilian Constitution. Violating this fundamental rule of the democratic game, viral content in WhatsApp with biased information or hate speech that does not enable the source or authorship to be identified grants anonymity that also goes against the principles of freedom and equality, offending the very purpose of political publicity.

Thus, the abuse of the mass media vehicle emerges, seriously undermining the rational communication process. Unfortunately, however, as Maitê Chaves Nakad Marrez points out, "the Internet is the field in which investigating abuses of power is least likely to happen, especially on the social networks"60, because, as he says, "it is a free, democratic environment with increasing accessibility"61. This is way "there is no single ruling published by the Superior Electoral Tribunal that affirms an abuse of mass media vehicles exclusively on social networks" 62.

The state of the art regarding the Brazilian electoral process (as well in the USA) repels the premise in which the network is democratic. In the examples here discussed, new technologies were used to pervert and make the debate artificial, making the voter easy prey for the predator's manipulation.

60 MARREZ, Maitê Chaves Nakad. Uso e abuso dos meios de comunicação social para favorecer candidaturas, parâmetros e limites à liberdade de comunicação e imprensa no processo eleitoral. In: PEREIRA, Luiz Fernando Casagrande; AGRA, Walber Moutra (Coords.). PECCININ, Luiz Eduardo (Org.). Abuso de poder e perda de mandato. Tratado de Direito Eleitoral. Tomo 7. Belo Horizonte: Fórum, 2018, p. 196.

61 MARREZ, Maitê Chaves Nakad. Uso e abuso dos meios de comunicação social para favorecer candidaturas, parâmetros e limites à liberdade de comunicação e imprensa no processo eleitoral. In: PEREIRA, Luiz Fernando Casagrande; AGRA, Walber Moutra (Coords.). PECCININ, Luiz Eduardo (Org.). Abuso de poder e perda de mandato. Tratado de Direito Eleitoral. Tomo 7. Belo Horizonte: Fórum, 2018, p. 196.

62 MARREZ, Maitê Chaves Nakad. Uso e abuso dos meios de comunicação social para favorecer candidaturas, parâmetros e limites à liberdade de comunicação e imprensa no processo eleitoral. In: PEREIRA, Luiz Fernando Casagrande; AGRA, Walber Moutra (Coords.). PECCININ, Luiz Eduardo (Org.). Abuso de poder e perda de mandato. Tratado de Direito Eleitoral. Tomo 7. Belo Horizonte: Fórum, 2018, p. 196. 
Hence, the myth of a free and democratic Internet, when there is no knowledge of its structure and clear self-regulatory policies are nonexistent, needs to be denounced. Doing so will fight the ignorance that leads the Judiciary to constantly chase after damaging facts, without the technical capabilities to understand them and evaluate their impact on the electoral process, and making them incapable, therefore, of protecting the public debate against pernicious influences. Recently, Minister Edson Fachin, in the Superior Electoral Tribunal, expressed the problem as follows:

(...) there are certain subjects that are coming to the courts, between them is this, in which we have the impression of being in a race behind the facts. As always remembered, and great Brazilian thinker Milton Santos wrote, "the trampling of the events unmakes the knowledge" and we go in this race trying to reconstruct it, having, sometimes, the perception that the technological revolution, especially in the second half of the 20th Century, left us with our feet in the end of the $19^{\text {th }}$ Century and our heads in the $21^{\text {st }}$ Century. Therefore, it is a kind of Procustes' law in which we try to adapt the fact and the circumstances. Here we have one such case, the boosting of content with all the vicissitudes that cybernetics projects in this group of ideas. ${ }^{63}$

In view of this, it is essential to train legal professionals to have a good knowledge of the ins and outs, in order to efficiently fight the bad use of new technologies.

\subsection{THE BAD USE OF TECHNOLOGY}

The colonization of private life in the network, which is damaging to selfdetermination and to citizens' freedom of information, is described by Perez Luño64 after reading the political scientist Giovanni Sartori, who denounces the

63 BRASIL. Electoral Superior Tribunal. Representação no. 23.2018.6.00.0000, Rapporteur Minister Luis Felipe Salomão, published in the Court session of Sept. 13, 2018, Minister Edson Facchin vote. Retrieved from: http:// www.tse.jus.br/jurisprudencia/decisoes/jurisprudencia, on Dec. 11, 2018.

64 PEREZ LUÑO, Antônio-Enrique. Teledemocracia, ciberciudadania y derechos humanos. Revista Brasileira de Políticas Públicas. Brasília, v. 4, n. 2, jul-dez 2014, p. 16. Retrieved from: https://www.publicacoesacademicas. uniceub.br/RBPP/article/view/2835, on Jan. 15, 2019. Original text: "Sartori responsabiliza a los nuevos medios tecnológicos y, en particular, a la TV de haber creado un post-pensamiento, que supone la anulación del pensamiento crítico. Sartori denomina a quienes hoy detentan las NT de la información "hombres-bestias", y los acusa de exaltar una "comunicación perenne", que incapacita para "articular ideas claras y diferentes". Lejos de forjar ciudadanos libres y responsables, las NT han promovido una "Lumpenintelligentia, un proletariado intelectual sin ninguna consistencia intelectual". 
annulment of critical thought by the excessive use of new technologies faced with the permanent flow of information that imposes inertia on critical thought. Sartori coins the phrase lumpenintelligentia to translate the impoverishment of intelligence and the lack of critical thought that the constant submission to the network imposes, making it harder to distinguish between right or wrong, true and false, and creating an intellectual proletariat.

A counterpoint to the Sartori, in an important dialectical exercise, Perez Luño65 also shows the contribution of Carl Sunstein, for whom the use of technology offers significant possibilities for political renewal of the democratic life, but with the risk of fragmentation that hinders collective options and political programs, possibly impairing the structural cohesion of the republican experience. For the North American scholar, the risk factor is the consumer user, preoccupied exclusively with personal gain projecting his activities in the network for the attainment of egoistical benefits. Francisco Balaguer Callejón ${ }^{66}$, in turn, is extremely preoccupied with the dismantling of constitutionalism, and with the insertion of global agents in local electoral process, outside the State itself and the Constitution.

From what can be seen, connection through the network, without intermediates and with the feeling of total freedom and kinship, was probably fed by a distrust of the traditional relations of communication, which are slower because they demand investigation of facts and source checking. It may also have occurred due to conservative forces union around specific subjects creating gated groups, exempt to criticism, and through the fear that self-absorbs and inhibits the expansion of ideas. Equally, it may also have been due to the hedonistic egoism of the consumer-predator. So there are many possibilities, but one fact remains

65 PEREZ LUÑO, Antônio-Enrique. Teledemocracia, ciberciudadania y derechos humanos. Revista Brasileira de Políticas Públicas. Brasília, v. 4, n. 2, jul-dez 2014, p. 17. Retrieved from: https://www.publicacoesacademicas. uniceub.br/RBPP/article/view/2835, on Jan. 15, 2019. Original text: "Sunstein entiende que la Red ha generado un tipo de usuario-consumidor, que ha creado, por tanto, unos hábitos de uso que pueden extrapolarse a todos los ámbitos de su empleo. La búsqueda del provecho individual, que es inherente a todas las transacciones comerciales en la Red, puede proyectarse a las actividades políticas. De este modo, el usuario que, en su condición de ciudadano debe asumir puntos de vista solidarios que trascienden a su mero interés individual, puede verse fagocitado por el usuarioconsumidor, que proyecta en todas sus actividades en la Red la obtención de beneficios inspirados en el egoísmo: los valores de la democracia republicana se ven suplantados por la "lógica económica del mercado"."

66 CALLEJÓN, Francisco Balaguer. LAS DOS GRANDES CRISIS DEL CONSTITUCIONALISMO FRENTE A LA GLOBALIZACIÓN EN EL SIGLO XXI. Roma: Rivita Nomos Le Atualittà Nel Diritto. N. 2, del 2018, p. 2. Retrieved from: http://www.nomos-leattualitaneldiritto.it/wp-content/uploads/2018/09/Callehon.-conv-11.05.pdf, on Jan. 23, 2019. 
true: transactions occur that greatly profit the giants of global technology. It is sufficient to note that the business implicating popular expression in the Donald Trump and Brexit cases both involved the handling of huge volumes of sensitive information (big data) deposited by the platform users (mainly Facebook), and sent to companies that bought it, for the purposes of analysis and data mining, in collaboration with electoral communication and publicity companies, which in turn, irrigate those connections using personality evaluation of the voter to guide him through the algorithm ${ }^{67}$.

Elias Jacob Menezes Neto and José Luis Bolzan de Morais explain that "[the] knowledge that comes from the analysis of these predictive algorithms is extremely opaque - although it makes the individual transparent for the analysis of those in power."68 These are simulated, speculative realities that end up guiding of the citizen through the interests of the one handling the technology. The risk format presented removes the legitimacy of the unlimited use of new technologies, and returns the problem for the pondering over the creation of public policies of control and prevention.

As alerted by Neto:

The idea that the predictive analysis system - simulated realities derive from high technology end up obscuring what they, in fact, are: speculative models of the future. Making decisions based on these systems, under the false assumption that their conclusions are scientific truths, has dire consequences for human rights. ${ }^{69}$

To unveil the capitalist face, the manipulator of the network, far from the democratic neutrality, on the other hand, does not mean to disregard other factors in the process of disintermediation, which is increasing in volume and speed, with new technologies in the long-lasting crisis of political representation.

67 This means that the business, aside from generating Money, gives even more power to the ruling elites.

68 NETO, Elias Jacob de Menezes; BOLZAN DE MORAIS, José Luís. ANÁLISES COMPUTACIONAIS PREDITIVAS COMO UM NOVO BIOPODER: MODIFICAÇÕES DO TEMPO NA SOCIEDADE DOS SENSORES. Revista NovOS Estudos Jurídicos - Eletrônica, Vol. 24 - n. 3 - set-dez 2018, p. 1.144. Retrieved from: https://siaiap32.univali.br/ seer/index.php/nej/article/view/13769/7808, on Jan. 15, 2019.

69 NETO, Elias Jacob de Menezes; BOLZAN DE MORAIS, José Luís. ANÁLISES COMPUTACIONAIS PREDITIVAS COMO UM NOVO BIOPODER: MODIFICAÇÕES DO TEMPO NA SOCIEDADE DOS SENSORES. Revista NovOS Estudos Jurídicos - Eletrônica, Vol. 24 - no. 3 - Sep-Dec 2018, p. 1.146. Retrieved from: https://siaiap32.univali. br/seer/index.php/nej/article/view/13769/7808, on Jan. 15, 2019. 


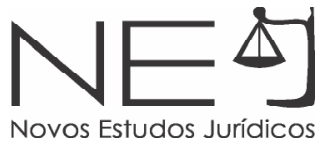

The one is the lack of effective channels of participation in the political process. One cannot believe that the citizen takes part in the political life only on each election, depositing the ballot for parties and candidates that are also only seen in that time. The fatigue of this model is evident with the increasing decrease in the number of voters that turn out to vote.

Following this path, we shall now discuss the alleged overcoming of parties by the digital present.

\subsection{IS IT TIME TO DO AWAY WITH POLITICAL PARTIES?}

In the context of usage, classified as weak, Perez Luño asserts that new technologies in the political process would strengthen the channels of parliamentary representation through the vast possibilities of communication with citizens, gathering important suggestions from the feedback stimulated by the network. ${ }^{70}$ His forecast is that representation would serve direct democracy in a subsidiary way, participation and popular will prevailing, without filters. ${ }^{71}$

Perez Luño, bringing the most relevant contributions to what he calls strong use of tele-democracy, offers following political reflections to support the idea of a society without political parties:

a) it enables the practice of a real and effective democratic power, returning it to the hands of the people;

b) it allows the shift of political prominence from parties to the citizens;

c) it avoids dysfunction in electoral systems, overcoming injustices, inequality and shortcomings of proportional systems.

d) it corrects representational distortion, such as populations that are not included or those with less proportional representation;

70 PEREZ LUÑO, Antônio-Enrique. Teledemocracia, ciberciudadania y derechos humanos. Revista Brasileira de Políticas Públicas. Brasília, v. 4, no. 2, Jul-Dec 2014, p. 18-20. Retrieved from: https://www.publicacoesacademicas. uniceub.br/RBPP/article/view/2835, on Jan. 15, 2019.

71 PEREZ LUÑO, Antônio-Enrique. Teledemocracia, ciberciudadania y derechos humanos. Revista Brasileira de Políticas Públicas. Brasília, v. 4, no. 2, Jul-Dec 2014, p. 20. Retrieved from: https://www.publicacoesacademicas. uniceub.br/RBPP/article/view/2835, on Jan. 15, 2019. 
e) it enables a joining of forces to block corruption in the system though the acts of stronger pressure groups;

f) it makes feasible a channel to eliminate the manipulation of public opinion. ${ }^{72}$

As an essential legal property, he notes that tele-democracy allows the actual and conscientious participation of citizens in the legislative process, democratizing Law and giving effectiveness to its commands. ${ }^{73}$

Perez Luño, although aware of the positions of Giovanni Sartori and Carl Sunstein noting the various shades and the risk of naïve simplifications or enthusiasm over new technologies for democracy, assures us that tele-democracy allows the ethical revival of the responsible and reciprocal practice of democracy. ${ }^{74}$ In his opinion, strong use of tele-democracy results in an overcoming of political parties in favor of direct connection with political representatives.

Perez Luño despite his optimistic defense warns to the juridical, political and ethical dangers of tele-democracy, as the risk of manipulation, the commodification of the public area, the impoverishment in the making of rules, the individualism, the emptying of communal values, invasion of privacy and cybercrime. Exactly what is being recently observed, removing trust from the participation through the network.

Oreste Massari, on the other hand, believes that politics without parties is akin to power without responsibility ${ }^{75}$, leading to a populist liberal democracy, although he acknowledges that parties have a tendency to adapt to digital activism, transforming themselves into something other than what society was

72 PEREZ LUÑO, Antônio-Enrique. Teledemocracia, ciberciudadania y derechos humanos. Revista Brasileira de Políticas Públicas. Brasília, v. 4, no. 2, Jul-Dec 2014, p. 15-20. Retrieved from: https://www.publicacoesacademicas. uniceub.br/RBPP/article/view/2835, on Jan. 15, 2019. PEREZ LUÑO, Antônio-Enrique. Teledemocracia, ciberciudadania y derechos humanos. Revista Brasileira de Políticas Públicas. Brasília, v. 4, no. 2, Jul-Dec 2014, p. 27. Retrieved from: https://www.publicacoesacademicas.uniceub.br/RBPP/article/view/2835, on Jan. 15, 2019

73 PEREZ LUÑO, Antônio-Enrique. Teledemocracia, ciberciudadania y derechos humanos. Revista Brasileira de Políticas Públicas. Brasília, v. 4, no. 2, Jul-Dec 2014, p. 20. Retrieved from: https://www.publicacoesacademicas.uniceub.br/ RBPP/article/view/2835, on Jan. 15, 2019.

74 PEREZ LUÑO, Antônio-Enrique. Teledemocracia, ciberciudadania y derechos humanos. Revista Brasileira de Políticas Públicas. Brasília, v. 4, no. 2, Jul-Dec 2014, p. 27. Retrieved from: https://www.publicacoesacademicas. uniceub.br/RBPP/article/view/2835, on Jan. 15, 2019.

75 MASSARI, Oreste. DAL PARTITO DI MASSA ALLA PARTITOCRAZIA SENZA PARTIT. Roma: Rivita Nomos Le Atualittà Nel Diritto. Antecipazioni convegni no. 3, del 2018, p. 30. Retrieved from: http://www.nomosleattualitaneldiritto.it/wp-content/uploads/2019/01/Massari-contributo-su-Zangara-3.2018.pdf, on Jan. 23, 2019. 
used to. An example is the Five Stars Movement (M5S) in Italy, owner of a digital platform named Rousseau ${ }^{76}$.

In Brazil, the existence of 35 parties, 34 of which spent a total of 1.7 billion Brazilian reals on the 2018 elections $^{77}$, and the ongoing registry application of more than $75^{78}$ on the electoral judicial branch, is a trend that does not validate the hypothesis of doing away with political parties, at least for the time being.

\section{MANIPULATION OF NETWORKS AS ABUSE OF MASS MEDIA}

The spread of false, manipulated or out-of-context information as a standard of intervention over elections ${ }^{79}$ raises the question of the abuse of mass media in its virtual form, inviting us to reflect on the liability, also, of the companies that supply this technology, in order to protect political guarantees and human rights.

The offer is of accountability for direct or indirect violation of political rights ${ }^{80}$, demanding the setting of parameters and review of the jurisprudence that establishes the "impossibility of a legal entity appearing as a defendant in judicial electoral investigations based on Art. 22 of Supplementary Law no. 64 of May 18, 1990". ${ }^{81}$ Manipulating communication through the social networks in order to affect the outcome of an election, besides diminishing political maturity and free thought, is an authoritarian tendency that disservices the democratic ideal, and

76 MASSARI, Oreste. DAL PARTITO DI MASSA ALLA PARTITOCRAZIA SENZA PARTIT. Roma: Rivita Nomos Le Atualittà Nel Diritto. Antecipazioni convegni no. 3, del 2018, p. 31. Retrieved from: http://www.nomosleattualitaneldiritto.it/wp-content/uploads/2019/01/Massari-contributo-su-Zangara-3.2018.pdf, on Jan. 23, 2019.

77 BRASIL. Superior Electoral Tribunal. Partidos políticos receberam R\$ 1,7 bilhão do Fundo Eleitoral em 2018. Brasília, 18 de janeiro de 2019. Retrieved from: http://www.tse.jus.br/imprensa/noticias-tse/2019/Janeiro/partidospoliticos-receberam-r-1-7-bilhao-do-fundo-eleitoral-em-2018, on Jan. 19, 2019.

78 BRASIL. Superior Electoral Tribunal. Brasil tem 75 partidos políticos em processo de formação. Brasília, January 25, 2019. Retrieved from: http://www.tse.jus.br/imprensa/noticias-tse/2019/Janeiro/brasil-tem-75-partidospoliticos-em-processo-de-formacao, on Jan. 19, 2019.

79 MELLO, Patrícia. Empresário bancam campanha contra o PT pelo WhatsApp. Jornal Folha de São Paulo from October 18, 2018. Retrieved from: https://www1.folha.uol.com.br/amp/poder/2018/10/empresarios-bancamcampanha-contra-o-pt-pelo-whatsapp.shtml, on Oct. 18, 2018.

80 "Companies should consider the probable impacts of their activities on human rights, which will lead, for example, to the monitoring of activities of its subsidiaries or entities under direct or indirect control. This diligence should also enable the identification and evaluation of any real or potential human rights violations resulting from the transnational commercial activity, and the prevention of those violations, which applies to the parent company, its subsidiaries, or any other company under its direct or indirect control" (SALDANHA, Jânia. Do direito soft ao direito hard em matéria de responsabilidade jurídica das empresas transnacionais por violação de direitos humanos. In: BOLZAN DE MORAIS, José Luis (Organizer). Estado \& Constituição: o fim do estado de direito. $1^{\text {a }}$ ed. Florianópolis: Tirant Lo Blanc, 2018, p. 228).

81 Citing as an example among thousands: BRASIL. Tribunal Superior Eleitoral. Agravo na Representação no. 321796, Rapporteur Minister Aldir Passarinho. Brasília: Diário Oficial de Justiça Eletrônico of November 30, 2010, p. 7-8. 
cannot be considered as only individual practice of political publicity, occasionally censored with a fine, as the Superior Electoral Tribunal has been doing. In this sense, it is imperative to put into effect the control of political communication without prior-censorship, while avoiding the naiveté of protecting an individual freedom that covers up barbaric acts committed by economic groups violating the authenticity of the election outcomes or personal gain. More than ever, it is imperative to relativize the economic individual right in favor of human rights.

Laying hold of this premise, the electoral jurisprudence will need to be reviewed, to classify the denaturing of network communications as abuse of mass media, dismissing the previous rulings, for example, in action no. 060096323, of rapporteur Minister Luís Felipe Salomão, in the ruling published during the Superior Electoral Tribunal session on September 13, $2018^{82}$.

In this precedent, examining the report against a businessman who was paying to boost Facebook posts about a candidate supported by him, even though that kind of spending could not have been done by a natural person ${ }^{83}$, the spending was declared illegal and the practice was prohibited to avoid the interference of economic power in the electoral process. But the final ruling was disappointing because the Court decided that the "intervention was minimal" in individual rights, without measuring its capacity to collective rights. When much, it was said to make "damage control, moving promptly to remove the illicit act, also applying a fine where necessary". ${ }^{84}$ The action was turned into

82 BRASIL. Superior Electoral Tribunal. Representação no. 0600963-23, Rapporteur Minister Luís Felipe Salomão. Brasília, decisão de 13 de setembro de 2018. Retrieved from: https://pje.tse.jus.br:8443/pje-web/ConsultaPublica/ DetalheProcessoConsultaPublica/documentoSemLoginHTML.seam?ca=dfe15ccdcadcfcf8b8cbd517b4b444151f d46e3e99c6ea4f9e8ed332b36c595f828e0852cf5522249fd2be22a2c82dde, on Jan. 19, 2019.

83 According to Art. 57-c of Law no. 9.504/97: "Art. 57-C. É vedada a veiculação de qualquer tipo de propaganda eleitoral paga na internet, excetuado o impulsionamento de conteúdos, desde que identificado de forma inequívoca como tal e contratado exclusivamente por partidos, coligações e candidatos e seus representantes. § 10 É vedada, ainda que gratuitamente, a veiculação de propaganda eleitoral na internet, em sítios: I - de pessoas jurídicas, com ou sem fins lucrativos; II - oficiais ou hospedados por órgãos ou entidades da administração pública direta ou indireta da União, dos Estados, do Distrito Federal e dos Municípios. § 20 A violação do disposto neste artigo sujeita o responsável pela divulgação da propaganda e, quando comprovado seu prévio conhecimento, o beneficiário à multa no valor de $\mathrm{R} \$ 5.000,00$ (cinco mil reais) a $\mathrm{R} \$ 30.000,00$ (trinta mil reais). § $20 \mathrm{~A}$ violação do disposto neste artigo sujeita o responsável pela divulgação da propaganda ou pelo impulsionamento de conteúdos e, quando comprovado seu prévio conhecimento, o beneficiário, à multa no valor de $\mathrm{R} \$ 5.000,00$ (cinco mil reais) a $\mathrm{R} \$ 30.000,00$ (trinta mil reais) ou em valor equivalente ao dobro da quantia despendida, se esse cálculo superar o limite máximo da multa. § 30 O impulsionamento de que trata o caput deste artigo deverá ser contratado diretamente com provedor da aplicação de internet com sede e foro no País, ou de sua filial, sucursal, escritório, estabelecimento ou representante legalmente estabelecido no País e apenas com o fim de promover ou beneficiar candidatos ou suas agremiações." (BRASIL. Presidência da República. Law no. 9.504, from September 30, 1997. Estabelece normas para as eleições. Brasília. Diário Oficial da União de $1^{\circ}$ de outubro de 1997. Retrieve from: http://www.planalto.gov.br/ccivil_03/LEIS/L9504.htm, on Dec. $4^{\text {th }}, 2018$ ).

84 BRASIL. Superior Electoral Tribunal. Representação no. 23.2018.6.00.0000, Rapporteur Minister Luis Felipe 


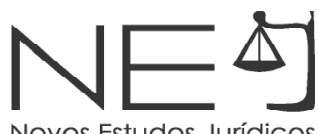

"other procedures", when it was a case of an electoral judicial investigation to inquire abuse, without making clear which and why, emptied the ruling of the due reasoning and revealed a lack of knowledge about the network as a communication media with greater power than radio or TV, and one that is manipulated more than these traditional channels.

The minimum one would have expected, acknowledging the limitations on the specific action in the precedent that was restricting the Court in some way, was that the Public Prosecutors Office, custus societatis, should have positioned itself and designed the investigation under the optics of the abuse of mass media. It could not have chosen not to act.

It should certainly have invoked the general clause of Article 22 of Supplementary Law no. 64, which regulates the "bad use of mass media vehicles in benefit of political party or candidate" 85 , as a reason to impose a fine, but also ineligibility and annulment of the politician's registration or inscription, even though he was only the recipient of the bad use result.

In a systemic reading of the legal framework, it is impossible to apply, in isolation, Articles 57-A and 57-J of Law no. 9.504/97, just as the liability of companies for cooperating in the illicit result must be reviewed using a set of rules in the Brazilian Civil Code ${ }^{86}$, Article 927, which sets out the duty to repair the damage derived from the illicit act, and confirmed by Article 19 of Law no. $12.965^{87}$, if the platform does not make arrangements to end the illicit act.

Salomão, published during the session of September 13, 2018. Retrieved from: http://www.tse.jus.br/jurisprudencia/ decisoes/jurisprudencia, on Dec. 11, 2018.

85 BRASIL. Presidência da República. Supplementary Law no. 64, from May 18, 1990. Estabelece, de acordo com o art. 14, $\S 9^{\circ}$ da Constituição Federal, casos de inelegibilidade , prazos de cessação e determina providências. Retrieved from: http://www.planalto.gov.br/ccivil_03/leis/lcp/Lcp64.htm, on Dec. 05, 2018.

86 BRASIL. Law no. 10.406, from January 10, 2002. Institui o Código Civil. Brasília. Published in the Diário Oficial da União of January 11, 2002. Retrieved from: http://www.planalto.gov.br/ccivil_03/LEIS/2002/L10406.htm, on Jan. 06, 2019.

87 BRASIL. Law no. 12.965, from April 23, 2014. Estabelece princípios, garantias, direitos e deveres para o uso da Internet no Brasil. Brasília. Published in the Diário Oficial da União of April 24, 2014. Retrieved from: http://www. planalto.gov.br/ccivil_03/_ato2011-2014/2014/lei//12965.htm, on Jan. 6, 2019. 


\section{CONCLUSION}

The new technologies used during the Brazilian elections imposed a reconfiguration of political communication and an overcoming of major paradigms, but also allowed the manipulation and the targeting of votes through fake news and hate speech, leading to a need to establish guidelines for the responsible use and the control of technology.

The distribution of fake, manipulated, or out-of-context news, as well as the use of private funding to pay for boosts in social networks as a standard of intervention in elections, demands protection of collective rights in opposition to freedom of speech in social networks, especially to cease the selling of this service, which is a bad use of mass media, blocking the app and holding liable all those responsible - candidates, parties, users and platforms.

In the absence of orders emanating from judicial rulings to prevent damage by the platforms in creating and distributing fake news, civil liability and damage reparation are essential, including blocking or prohibiting the platform from operating in the country.

Prior to network control, digital education is needed to disarm the manipulative communication fiefdoms, as well as increased dialog with the many actors of the democratic society, and a search of international governance through treaties, for the protection of political rights.

To combat ignorance and enable adequate usage and proportional control, legal professional, in particular state branches, must qualify themselves to avoid running behind the facts, with an analog head in a fast paced digital world. This can be done using, for example, contributions from society during public hearings, listening to scientists in various fields of $\mathrm{k}^{\text {no }}$ wledge, and essentially, adopting as a benchmark the protection of citizenship, to safeguard and implement the human rights of society. 


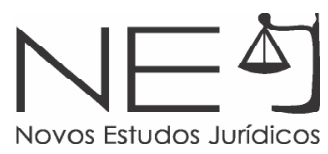

\section{REFERENCES}

AGUADO, Pedro García y MENA, Francisco Castaño. A salvo em la red Cómo proteger y educar a tus hijos en internet y las redes sociales. Barcelona: Penguin Random House Grupo Editorial, 2017.

ARENDT, Hannah. A Promessa da Política. São Paulo: Editora Difel, 2008.

BALAGUER CALLEJÓN, Francisco. LAS DOS GRANDES CRISIS DEL CONSTITUCIONALISMO FRENTE A LA GLOBALIZACIÓN EN EL SIGLO XXI. Rivita Nomos Le Atualittà Nel Diritto. Convegni. 2, de 2018. Retrieved from: http://www.nomos-leattualitaneldiritto.it/wp-content/ uploads/2018/09/Callehon.-conv-11.05.pdf.

BOLZAN DE MORAIS, José Luis. O fim da geografia institucional do Estado. A "crise" do Estado de Direito. In: BOLZAN DE MORAIS, José Luis (Organizer). Estado \& Constituição: o fim do estado de direito. $1^{\mathrm{a}}$ ed. Florianópolis: Tirant Lo Blanc, 2018, p. 17-37.

BOLZAN DE MORAIS, José Luis; VIEIRA, Gustavo Oliveira e SALDANHA, Jânia Maria Lopes. Entre o global e o local: constituição e direitos humanos In: BARROS, Flaviane de Magalhães (Organizer). Convencionalidade e sistema de justiça: dissonâncias e consonâncias entre a jurisdição internacional dos direitos humanos e as decisões do sistema judicial brasileiro. $1^{\text {a }}$ ed. Florianópolis: Tirant Lo Blanc, 2018, p. 17-37.

BRASIL. Presidência da República. Constituição da República Federativa do Brasil. Publicada no Diário Oficial da União of October 5, 1988. Retrieved from: http://www.planalto.gov.br/ ccivil_03/Constituicao/Constituicao.htm, on Dec. $4^{\text {th }}, 2018$.

. Presidência da República. Supplementary Law nº 64, of May 18, 1990. Estabelece, de acordo com o art. 14, § $9^{\circ}$ da Constituição Federal, casos de inelegibilidade, prazos de cessação e determina providências. Retrieved from: http://www.planalto.gov.br/ccivil_03/leis/ Icp/Lcp64.htm, on Dec. 5, 2018.

Presidência da República. Law no 9.504, of September 30, 1997. Estabelece normas para as eleições. Brasília, Diário Oficial da União de $1^{\circ}$ de outubro de 1997. Retrieved from: http://www.planalto.gov.br/ccivil_03/LEIS/L9504.htm, on Dec. $4^{\text {th }}, 2018$.

Presidência da República. Law no 10.406, of January 10, 2002. Institui o Código Civil. Brasília. Publicada no Diário Oficial da União de 11 de janeiro de 2002. Retrieved from: http://www.planalto.gov.br/ccivil_03/LEIS/2002/L10406.htm, on Jan. 6, 2019.

Presidência da República. Law n 12.527, of November 18, 2011. Regula o acesso a informações previsto no inciso XXXIII do art. $5^{\circ}$, no inciso II do $\S 3^{\circ}$ do art. 37 e no $\$ 2^{\circ}$ do art. 216 da Constituição Federal (...). Brasília. Diário Oficial da União de 18 de novembro de 2011. Retrieved from: http://www.planalto.gov.br/ccivil_03/_ato2011-2014/2011/lei//12527.htm, on Jan. 30, 2019. 
Presidência da República. Law no 12.695, de 23 de abril de 2014. Estabelece princípios, garantias, direitos e deveres para o uso da internet no Brasil. Brasília. Diário Oficial da União de 24 de abril de 2014. Retrieved from:http://www.planalto.gov.br/ccivil_03/_ato20112014/2014/lei/l12965.htm, on Jan. 06, 2019

Supreme Federal Tribunal. Audiência Pública Simultânea Convocada para Discutir Aspectos dos Arts. 10 e 12, II e IV, da Lei no 12.965/2014 - Marco Civil da Internet (ADI 5.527, Rel. Min. Rosa Weber) - e a Suspensão do Aplicativo WhatsApp por Decisões Judiciais no Brasil (ADPF 403, Rel. Min. Edson Fachin). Brasília, ended in June 5, 2017. Retrieved from: http://www.stf.jus.br/arquivo/cms/audienciasPublicas/anexo/ ADI5527ADPF403AudinciaPblicaMarcoCivildalnterneteBloqueioJudicialdoWhatsApp.pdf, on Jan. 18, 2019.

. Supreme Federal Tribunal. Arguição de Descumprimento de Preceito Fundamental $n^{\circ}$ 403. Relator Ministro Edson Facchin. Decisão de 19 de julho de 2016. Retrieved from: http://stf.jus.br/portal/diarioJustica/verDiarioProcesso.asp?numDj=152\&dataPublicacaoDj $=01 / 08 / 2016 \&$ incidente $=4975501 \&$ codCapitulo $=6 \&$ numMateria $=117 \& \operatorname{codMateria}=10$, on Jan. 19, 2019.

SupremeFederalTribunal.Questão deOrdemno RecursoExtraordinário comAgravo $\mathrm{n}^{\circ}$ 1.054.490. Relator Ministro Roberto Barroso. Brasília, 05 de outubro de 2017, p. 6. Retrieved from: http://redir.stf.jus.br/paginadorpub/paginador.jsp?docTP=TP\&docID=14474833, on Jan. 23, 2019.

Superior Electoral Tribunal. Resultado da eleição. Retrieved from: http://www.tse. jus.br/eleicoes/estatisticas/estatisticas-eleitorais, on Jan. 13, 2019.

Superior Electoral Tribunal. Representação $n^{\circ}$ 23.2018.6.00.0000, relatada pelo Ministro Luis Felipe Salomão, publicado em sessão do TSE de 13 de setembro de 2018, voto do Ministro Edson Facchin. Retrieved from:http://www.tse.jus.br/jurisprudencia/decisoes/ jurisprudencia, on Dec 11, 2018.

Superior Electoral Tribunal. Partidos políticos receberam $R \$ 1,7$ bilhão do Fundo Eleitoral em 2018. Brasília, 18 de janeiro de 2019. Retrieved from: http://www.tse.jus.br/ imprensa/noticias-tse/2019/Janeiro/partidos-politicos-receberam-r-1-7-bilhao-do-fundoeleitoral-em-2018, on Jan. 19, 2019.

Superior Electoral Tribunal. Brasil tem 75 partidos políticos em processo de formação. Brasília, 25 de janeiro de 2019. Retrieved from: http://www.tse.jus.br/imprensa/ noticias-tse/2019/Janeiro/brasil-tem-75-partidos-politicos-em-processo-de-formacao, on Jan. 19, 2019.

. Superior Electoral Tribunal. Agravo na Representação $n^{\circ}$ 3217-96, relatado pelo Ministro Aldir Passarinho. Brasília: Diário Oficial de Justiça Eletrônico of November 30, 2010, p. 7-8. 
Superior Electoral Tribunal. Representação no 0600963-23, relatada pelo Ministro Luís Felipe Salomão. Brasília, decisão de 13 de setembro de 2018. Retrieved from: https://pje.tse.jus.br:8443/pje-web/ConsultaPublica/DetalheProcessoConsultaPublica/ documentoSemLoginHTML.seam?ca=dfe15ccdcadcfcf8b8cbd517b4b444151fd46e3e99c6ea 4f9e8ed332b36c595f828e0852cf5522249fd2be22a2c82dde, on Jan. 19, 2019.

Superior Electoral Tribunal. Representação $n^{\circ}$ 23.2018.6.00.0000, relatada pelo Ministro Luis Felipe Salomão, publicado em sessão do TSE de 13 de setembro de 2018. Retrieved from:< http://www.tse.jus.br/jurisprudencia/decisoes/jurisprudencia>, on Dec. 11, 2018.

CASTELLS, Manuel. A sociedade em rede. A era da informação: economia, sociedade e cultura. Vol.1. Tradução Roneide Venâncio Majer. 18 edição, revista e ampliada. São Paulo: Paz e Terra, 2017.

. Redes de indignação e esperança: movimentos sociais na era da internet. Rio de Janeiro: Zahar Editores, 2013.

DIAS, P. Y. Regulação da internet como administração da privacidade. Revista de Direito, Estado e Telecomunicações. Brasília, v. 9, n. 1, May, 2017, p. 172.

DUTRA, Deo Campos e OLIVEIRA JÚNIOR, Eduardo F. Ciberdemocracia: $A$ internet como Ágora Digital. Revista Direitos Humanos e Democracia. Editora UNIJUI, Ano 6, n 11, Jan./Jun. 2018, p. 134-166.

EUA. CRIMINAL NO. 18 U.S.C. §§ 2, 371, 1349, 1028A. EUA vs INTERNET RESEARCH AGENCY et. al. Retrieved from: https://www.justice.gov/file/1035477/download, on Dec. 16, 2018.

FERRAJOLI, Luigi. Poteri selvaggi: La crisi dela democrazia italiana. Roma: Laterza, 2011.

GOMES, Helton Simões. Voto em casa e pelo celular! Como é a tecnologia em eleições pelo mundo. Uolnotícias.com. Published on October 27, 2018. Retrieved from: https://noticias.uol. com.br/tecnologia/noticias/redacao/2018/10/27/votar-em-casa-e-com-blockchain-comoe-a-tecnologia-em-eleicoes-pelo-mundo.htm, on Jan. 15, 2019.

GALLEGO, Esther Solano. La whatsapización de la politica y la nueva verdad. Revista Contexto, n. 196, November 21, 2018. Retrieved from: https://ctxt.es/es/20181121/Firmas/23006/ elecciones-brasil-whatsappizacion-politica-fake-news-esther-solano.htm, on Nov. 26, 2018.

GENESINI, Silvio. A pós-verdade é uma notícia falsa. São Paulo: Revista USP, n. 116, Jan. mar 2018, p. 45-58.

GRACO, Abraão Soares Dias dos Santos; SILVA ÂNGELUS, Alcione. Partidos políticos analógicos e a necessidade de mediação em uma sociedade digital. In: GUERRA, Arthur Magno e Silva; BARACHO JÚNIOR, José Alfredo de Oliveira; BERNARDES, Flávio do Couto (Orgs.). 30 Anos de Democracia. Belo Horizonte: Editora D’Plácido, 2018, p. 126. 
JULIOS-CAMPUZANO, Alfonso de. La Crisis de Legitimidad em Las Democracias Contemporaneas. Partidos Politicos, Movimentos Sociales Y Ciudadania Responsable. In: BOLZAN DE MORAIS, José Luis (Organizer). Estado \& Constituição: o fim do estado de direito. $1^{\mathrm{a}}$ ed. Florianópolis: Tirant Lo Blanc, 2018, p. 157-185.

LARSON, Christina. Who needs democracy when you have data? Here's how China rules using data, Al, and internet surveillance. Published on August 20, 2018. Retrieved from: https://www. technologyreview.com/s/611815/who-needs-democracy-when-you-have-data/, on Nov. 26, 2018.

LEVITSKY, Steven; ZIBLATT, Daniel. Como as Democracias Morrem. Rio de Janeiro: Zahar, 2018.

LOBO, Edilene e MOREIRA, Pedro Henrique Costa e. Fake news e autenticidade das eleições brasileiras. In: OLIVEIRA, Armando Albuquerque et al (Coords.). Teoria da democracia e da filosofia do Estado e direito constitucional. Zaragoza : Prensas de la Universidad de Zaragoza, 2019, p. 285-300.

LUÑO, Antônio-Enrique Pérez. Teledemocracia, cibercidadania y derechos humanos. Revista Brasileira de Políticas Públicas, Brasília, v. 4, n. 2, 2014, p. 8-46.

LIMBERGER, Têmis e SALDANHA, Jânia Maria Lopes. Cibercidadania no mundo globalizado: o desafio das novas tecnologias e a concretização dos direitos humanos nas democracias contemporâneas. ANUARIO DE DERECHO CONSTITUCIONAL LATINOAMERICANO, AÑO XVIII, 2012, p. 215-230, Bogotá.

MAINIERI, Tiago e RIBEIRO, Eva Márcia Arantes Ostrosky. A comunicação pública como processo para o exercício da cidadania: o papel das mídias sociais na sociedade democrática. Revista Organicom. USP, Ano 8, n 14, $1^{\circ}$ semester of 2011, p. 50-61.

MARREZ, Maitê Chaves Nakad. Uso e abuso dos meios de comunicação social para favorecer candidaturas, parâmetros e limites à liberdade de comunicação e imprensa no processo eleitoral. In: PEREIRA, Luiz Fernando Casagrande; AGRA, Walber Moutra (Coords.). PECCININ, Luiz Eduardo (Org.). Abuso de poder e perda de mandato. Tratado de Direito Eleitoral. Tomo 7. Belo Horizonte: Fórum, 2018, p. 196.

MASSARI, Oreste. DAL PARTITO DI MASSA ALLA PARTITOCRAZIA SENZA PARTIT. Roma: Rivita Nomos Le Atualittà Nel Diritto. Antecipazioni convegni n 3, del 2018, p. 10. Retrieved from: http://www.nomos-leattualitaneldiritto.it/wp-content/uploads/2019/01/Massari-contributosu-Zangara-3.2018.pdf, on Jan. 23, 2019.

MÜLLER, Leonardo. Primeira eleição do mundo auditada por blockchain é realizada em Serra Leoa. Techmundo.com. Published on March 16, 2018. Retrieved from: https://www.tecmundo. com.br/software/128285-primeira-eleicao-mundo-auditada-blockchain-realizada-serraleoa.htm, on Jan. 15, 2019. 
NETO, Elias Jacob de Menezes; BOLZAN DE MORAIS, José Luís. ANÁLISES COMPUTACIONAIS PREDITIVAS COMO UM NOVO BIOPODER: MODIFICAÇÕES DO TEMPO NA SOCIEDADE DOS SENSORES. Revista Novos Estudos Jurídicos - Eletrônica, Vol. 24 - n. 3 - set-dez 2018, p. 1.1291.154 Retrieved from: https://siaiap32.univali.br/seer/index.php/nej/article/view/13769/7808, on Jan. 5, 2019.

POPPER, Karl. A lógica da pesquisa científica. Translators Leonidas Hegenberg e Octanny Silveira da Mota. São Paulo: Cultrix, 1974.

RIVERO, Ángel, ZARZALEJOS, Javier y PALACIO, Jorge (Coordinators). Geografia del populismo Um viaje por el universo del populismo desde sus orígenes hasta Trump. Madrid: Tecnos, 2017. $455 \mathrm{p}$.

ROCHA, Luciano. Região na Rússia conduz a primeira eleição em blockchain do país. Criptomoedasfácil.com. Published on December 20, 2018. Retrieved from: https://www. criptomoedasfacil.com/regiao-na-russia-conduz-a-primeira-eleicao-em-blockchain-dopais/, on Jan. 16, 2019.

TAVARES, João Felipe Chagas e TEIXEIRA, Luiz Felipe Drummond. BLOCKCHAIN: DOS CONCEITOS ÀS POSSÍVEIS APLICAÇÕES. In: POLIDO, Fabricio Bertini Pasquot; ANJOS, Lucas dos; BRANDÃO, Luíza Couto Chaves (Orgs.). TECNOLOGIAS E CONECTIVIDADE DIREITO E POLÍTICAS NA GOVERNANÇA DAS REDES. Belo Horizonte: Instituto de Referência em Internet e Sociedade, 2018, p. 119 a 132.

WOLKMER, Antônio Carlos. Introdução aos fundamentos de uma teoria geral dos "novos" direitos Retrieved from: http://www.egov.ufsc.br/portal/sites/default/files/593-2009-1-pb. pdf, on Jan. 16, 2019.

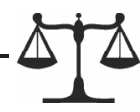

